\title{
Economic Sustainability of Small to Medium Enterprises (SMEs) in Zimbabwe: The Impact of Fiscal Incentives and Entrepreneur Work Engagement
}

\author{
Moses Jachi* Nevermind Muchongwe \\ Manicaland State University of Applied Sciences P. Bag 7001, Mutare, Zimbabwe
}

\begin{abstract}
This study aimed at investigating the impact of fiscal incentives and work engagement on economic sustainability of SMEs in Zimbabwe. The study adopted fiscal incentives, representing external factors, and work engagement, representing factors internal to the organization, as independent variables and economic sustainability assessed in terms of profitability through turnover and return on investment (ROI) as the dependent variable. Survey data was obtained from 120 SMEs in Zimbabwe using semi-structured questionnaires. Research participants were purposively selected to ensure the results are representative of all players within the SME subsector in Zimbabwe. Correlation and regression analysis were used to test the hypotheses that fiscal incentives and work engagement are positively associated with economic sustainability of SMEs in Zimbabwe. The study established that there is a significant positive relationship between fiscal incentives \& work engagement and economic sustainability of SMEs in Zimbabwe. However, it was revealed that most entrepreneurs in Zimbabwe were not aware of the availability of and their eligibility for fiscal incentives. As such, the study concluded that economic sustainability of SMEs in Zimbabwe is mainly driven by internal people factors than the influence of fiscal incentives. The study also revealed that majority of entrepreneurs in Zimbabwe were pushed into establishing businesses by negative economic conditions such as unemployment than free-will and business enthusiasm. This establishment therefore, confronts the self-determination theory as it proved limited insight into the psychological mechanisms involved in driving entrepreneurial spirit. The study however further concluded that if properly administered, fiscal incentives have the capacity to significantly impact economic sustainability of SMEs in Zimbabwe. Study findings will contribute towards the development of a more satisfactory descriptive theory for a broader approach to economic sustainability of SMEs in Zimbabwe
\end{abstract}

Keywords: Fiscal incentives, Work engagement, Economic sustainability

DOI: $10.7176 / \mathrm{PPAR} / 9-12-03$

Publication date: December $31^{\text {st }} 2019$

\section{Introduction}

Literature emphasises the importance of the role played by SMEs in the overall growth and development of both developed and developing economies (Kirkby \& Watson, 2003; Shar, 2006; Asikhia, 2010; Osim, 2010; Dickinson, 2013). SMEs as popularly known for their ability to harness local resources, labour intensive nature, dominant dependence on local sources of raw materials and components, and flexibility in creating linkages with other sectors of the economy, have proved to be an important cog in the engine of economic growth (Shar, 2006; Ishengoma \& Kappel, 2006). This therefore entails that economic players including governments should focus and further interests in the subsector in their endeavour to promote economic development. The Zimbabwean economy, since the early eighties has been dependent largely on agriculture (Stoneman \& Thompson, 1994), this was a direct result of the enormity of revenues generated from the agricultural subsector. As a result, no reasonable attention has been directed towards positioning SMEs on the economic development highway or the development of the SME sub-sector.

Factors determining sustainability of SMEs can be broadly categorised into internal and external factors. Internal factors are those factors intrinsic and embedded within the organisation, such as the influence of owner entrepreneurs, whereas external factors entail factors pertaining to the external environment, including factors such as government policy. The theory supporting sustainability as being driven by entrepreneur work engagement as a key organizational internal sustainability driver was born out of an interest in the study of intrinsic motivation, defined as doing something for its own sake, out of interest and enjoyment (Van den Broeck, et al., 2011). In addition to showing how feelings of work engagement (locus of causality) influence the level of innovation, research has found that innovation flourishes when people feel like they are married to their work environment, which ultimately yields a feeling of competence. Key observations can be drawn from the behaviors of entrepreneurs in their manifestation of intrinsically driven energies through expansion and growth of their businesses.

Research confirm that there is a strong association between work engagement and overall business success (Muntaha, et al., 2013). This belief resonates well with their earlier work on gendered engagement as they allude that work engagement presents a positive psychological state of the mind capable of ploughing enormous 
benefits to the entity as a whole in the long run. Most SMEs in Zimbabwe are populated and manned by family workers while of late this people performance indicator has never been interrogated through research to ascertain its influence in driving overall performance and ultimate sustainability in the Zimbabwean context. In view of the fact that Zimbabwe is currently struggling to survive the economic mayhem, SMEs have proved very useful as the 'new seed' to industrialization and modernization, as the sector is richly endowed with enumerable levels of innovation and creativity (Baregheh, et al., 2012; Salavou \& Lioukas, 2003). Work engagement stands as one construct that should never be left out in any innovation driven debate, SMEs included. SMEs' economic sustainability anchors heavily on the mix of; character, competencies, caliber, qualities and or work attitudes of the people running the economic enterprises. Innovation and creativity stand as latent effects of work engagement from which the so desired economic sustainability of SMEs is expected to accrue (Upasna, 2013). Gaynor (2002) pronounces that entrepreneurial intensity is a manifestation and confirmation of an engaged workforce. It is aptly rare to witness a scenario where work engagement and employee engagement being at contrast owing to the strong marriage between the two constructs; they work hand in glove.

In Zimbabwe, the year 1991 marked the birth of economic reforms, and this heralded the possibility of a complete turnaround on the central government's attitude and view towards realisation of the importance of the role played by private sector participants and Small and Medium Enterprises in fostering economic activity (Kirkby \& Watson, 2003), mainly focusing on the most wanted growth and development (Muvuma, et al., 2005). Policy frameworks targeting the Small and Medium enterprises clearly demonstrated the government's potential realisation and appreciation of the economic subsection (Nyoni, 2002). In Zimbabwe, a number of economic blue prints aimed at revitalising the economy have always been crafted, these include, the Zimbabwe Program for Economic and Social Transformation - ZIMPREST (1996-2000), the Millennium Economic Recovery Program - MERP (2000), the National Economic Revival Programme - NERP (2003), the Macroeconomic Policy Framework (2005-2006), the Expansionary Monetary Policies (2003-2008), the National Economic Development Priority Programme - NEDPP (2007), the Short-term Emergency Recovery Programme (2009), the Zimbabwe Agenda for Sustainable Socio-economic Transformation $(2015$ - 2018) and the Ten-point Plan (2015). These policy frameworks had great economic implications, however, with the exception of ZIMASET and the subsequent ten-point plan, majority of them lacked emphasis on the need to fully integrate the SME subsector into the economic development highway, and most of other programs targeting the SME subsector lacked coordination (Nyoni, 2002).

There are a number of benefits associated with SME development; these include innovativeness, relatively low initial capital requirements and growth potential (Asikhia, 2010). These enterprises can present a number of solutions to a struggling nation like Zimbabwe. Considering the soaring unemployment challenges facing the Zimbabwean economy, SMEs are playing a crucial role in enhancing livelihoods (Asikhia, 2010) since the greatest percentage of the employed population are in the sector. SMEs however, face a number of problems the majority of which can be addressed by the government through policy frameworks, taxation policy being one of them (Nyoni, 2002; Dickinson, 2013). The importance of the role played by SMEs in the overall growth and development of the economy has been greatly appreciated by a majority of both developed and developing economies (Kirkby \& Watson, 2003; Shar, 2006; Osim, 2010; Dickinson, 2013). SMEs promote sustainability in the context of industrial dispersal and industrial diversification, and they account for more than half of economic activity, thus employment and sales in a number of economies (Udechukwu, 2003).

In his book 'The Wealthy of Nations', Adam Smith (1976) presented his canons of taxation, one of which emphasised on the need to design tax policy so as not to enrich the treasury of a nation at an unprecedented expense to its citizens (Smith, 1976). However, taxation has failed to meet such requirements and it is found to be so burdensome to people than it benefits the sovereign (Dickinson, 2013). It is therefore government's responsibility to create a legislative and fiscal climate that is pro-enterprising and encouraging investment, growth and survival of sustainable enterprise (Poutziouris, et al., 1999; Asikhia, 2010; Dickinson, 2013). In a bid to address problems faced by SMEs, enhance business growth, investment and economic development, nations have increased interests in taxation policies that reduced cost of investment (Koves, 1992; Shar, 2006; Dickinson, 2013) and strengthen the link between effort and reward (Shar, 2006; Asikhia, 2010). The most common forms of fiscal incentives being accelerated depreciation on capital investments, tax credits and tax holidays (Shar, 2006). Following results from a study by the World Bank, investment promotion has proved to be an important objective of tax policy in a number of developing economies. This same notion was supported by Delong and Summers (1991). Delong and Summers subscribed to the idea of incentivising capital investment and further explored on how it positively impacts on socio-economic well-being of nations as a result of positive indirect flow of benefits, thereby giving a proper justification for investment promotion. This same notion was also supported by Scott (1989).

However, Boadway \& Shar (2007) provided a somewhat solid argument on the implications that incentives might have on investments. They argued that if incentives are provided to enterprising firms in an environment characterised by perfect competition, they will not result in an equitable distribution of resources (Boadway \& 
Shar, 2007), since it results in different pre-tax returns for different investments. This idea was supported by Fisher (2010) when he also argued against tax breaks, viewing them as a waste of state resources which could in turn be used to provide public service (Fisher, 2010). In his analysis of the three business tax breaks passed by the California Legislature in 2008 and 2009, Fisher argued that it is clear that sustaining fiscal incentives would result in substantive opportunity costs to the economy, considering the resources could have been successfully applied to the provision of public services (Alan \& Fisher, 2004; Fisher, 2010). The use of fiscal incentives to enhance economic development, according to Fisher, cannot bring forth the intended results, given that a number of the beneficiaries to such incentives are economic players who would have contributed nothing in line with the government's economic objectives (Alan \& Fisher, 2004; Fisher, 2010).

King (1984) also pointed out the negative implications of fiscal incentives. He postulated that fiscally incentivising investment is associated with equity violations which are usually overlooked (King \& Don, 1984; Zee, et al., 2002). In contrary to the above negative concerns about fiscal incentives, according to Lerner (1998), there is "no proof that incentive programs for informal investors are not necessary" (Lerner, 1998). It can also be observed from economic literature that an example of Keynesian solutions to problems of employment, which can help a nation make considerable strides towards full employment, is making use of taxation policy (Lipsey, 2007). However, the efficacy of fiscal incentives in achieving their intended objectives in poor economic systems associated with considerably reduced taxable earnings, high operational costs, and other structural rigidities remains questionable. Furthermore, in environments associated with capacity underutilisation, availing fiscal incentives may be unjustifiable. If, however, economic development is hindered by cost of investment, fiscal incentives may play a paramount role in propelling growth.

\section{Statement of the problem}

The sustainability of SMEs world over, leverages heavily on factors external to the organization, thus public policy and internal people factors. People factors as key internal drivers of sustainability, chief among them entrepreneurial intensity summarized as innovation and creativity, have been noted as driving forces towards attainment of economic sustenance (Upasna, 2013). Ideally, Peters \& Waterman (1982) express this as "productivity through people" which in this study is reckoned holistically as work engagement, do present realistic justification for the potential existence of a strong link between work engagement and economic sustainability of SMEs (Aleksandra, et al., 2017). On the other hand, as is the case with many other developing nations, Zimbabwe offers fiscal incentives in various forms, including tax exemption periods, preferential rates of taxation, as well as capital allowances as key external forces to aid entrepreneurial efforts and drive business sustainability. These fiscal incentives are available to beneficiaries on the basis of economic sector, line of trade, and location of the investment activity, (ZIMRA, 2014), and are mainly aimed at promoting investment and economic sustainability of Small and Medium Enterprises. However, there is still little evidence on whether these incentives do really promote the economic sustainability of local SMEs. Also, very few studies contextualized in Zimbabwean experiences have interrogated the intensity of influence that work engagement holds on economic sustainability of SMEs rampant across sectors of the Zimbabwean economy. This study seeks to plug the research gap through theorizing work engagement as a key internal dimension and fiscal incentive as the key external dimension fostering economic sustainability of Zimbabwean SMEs.

\section{Literature review}

\subsection{The Self-Determination Theory (SDT)}

The roots to the self-determination model can be traced from the idea that human beings have a natural tendency to expend their energies, account for their actions, show originality to learning and understanding things, and the consequential desire to do good at work and play (Robert \& Ankli , 2012). Human strengths, motives, capacities and optimal functioning are said to owe their origins to positive psychology, whose execution follows the principles of natural free-will which then calls for autonomous regulation as the chief driving force. Catherine (2015) agrees that the model proffers a strong theoretical basis to examine the relationship between human needs satisfaction (e.g. autonomy, competence and relatedness) and entrepreneur's behavior in the work context. Thus, based on self- determination framework, the authors reasoned that when entrepreneurs have a sense of competence, autonomy and relatedness, emotional bond between themselves and their work is possible. It is prudent to treat the theory as a cognitive assessment and evaluation model, which illuminates the outcomes of extrinsic motivators on intrinsic motivation.

Intrinsic motivation denotes self-drive towards spontaneous satisfaction and self-fulfillment of personal life goals while extrinsic type points to external push forces to the individual work attitude as sourced from the surrounding environment. The former appears closely related to the SD theory owing to the self being the initiator and engine of work habits since people perform the given activity for its own sake out of enjoyment as they make choices purely out of interest (Richa, et al., 2012). This whole idea about motivation is found slotted on the self-actualization map as championed by Maslow's needs hierarchy. Further, perception of the self as 
marked by one's emotional and psychological needs, personal life goals and aspirations, culture, individual dynamism, and the impact of social environments are some of the key issues that determine one's ability to selfactualize which is the focus of SDT. The success speeches and winning stories told of in organizations bolster awareness on how both forms of motivation affect performance and influence work satisfaction and again is vital when one considers the complex conduct of employees who in volatile labor-environment find themselves with an ambivalent attitude towards their enterprise. Van, et al., (2011) mentioned that workaholism, loyalty behavior, resilience, self-determination, brand ambassadorial attitude and commitment to success are some of the key tenets that define the effects of self-determination which are expected to manifest in the entrepreneur.

The SDT is a motivation and personality theory that presents the role of self-motivation in influencing behaviour and personality patterns (Ryan, et al., 1997). Through the application the theory in empirical processes, literature establishes three main needs that are essential for the optimal functioning of the natural propensities of growth and integration as well as for constructive social development and personal well-being. The identified needs are competence (White, 1963; Harter, 1978), relatedness (Reis, 1994; Baumeister \& Leary, 1995) and autonomy (De Charms, 1968; Deci, 1975). Studies based on the self-determination theory also examined the effects of environmental factors on personal behaviour motivation and well-being, whose findings mainly point to the thwarting of the three identified competence, relatedness and autonomy needs. Majority of these studies specified conditions which promote constructive behaviour as well as those that impede self-motivation.

The current study, through a review of previous studies guided by the self-determination theory seek to assess and establish the main factors behind pro-enterprising behaviour of entrepreneurs within Zimbabwe's SME sub-sector. Motivation concerns all aspects of intention and activation. In the real world, the concept of motivation is highly valued because of its consequences. It can therefore play an important role in assessing behaviours of entrepreneurs as they in most cases play a double-fold role of a manager/leader and investor. People are motivated to act in certain ways by different factors, ranging from their valuing of an activity to a reaction to a strong external coercion. This contrast between internal motivation and a response to external pressures is common in mankind, across all spheres of life. The idea of whether people behave in a certain fashion out of their interest and values, or for reasons external to the self, is significant to understanding of dynamics in every culture or trade (Johnson, 1993), representing dimensions through which actors can understand their own behaviours and that of others (Heider, 1958; De Charms, 1968; Connell \& Wellborn, 1991).

Contrasting between self-motivated individuals and those whose behaviour is driven by external factors reveal that those self-motivated are more interested, committed and confident in their undertakings, which elements manifest through enhanced performance, perseverance and creativity (Deci \& Ryan, 1991; Sheldon, et al., 1997), heightened vitality (Nix, et al., 1999), self-esteem (Deci \& Ryan, 1995) and general well-being (Ryan, et al., 1995). These disparities have been seen to exist even among people of similar competencies or selfefficacy for their roles or trades. The self-determination theory managed to ascertain different forces behind people's actions, through the identification of different types of motivation and their specific consequences for learning, performance, personal experience and well-being, and providing a set of principles guiding the development and sustenance of each type of motivation. Thus, the self-determination theory recognises a positive thrust to human nature and provides an account of passivity, alienation and psychopathology. Knowledge concerning the nutrients essential for positive motivation and experience which open doors to enhanced performance and well-being is of great significance. It can be of great relevance to policy makers concerned with economic development through the promotion of pro-enterprising behaviour, because it speaks to the conditions that promote behaviour regulation. It is also important to entrepreneurs, managers and leaders, whose interests are to facilitate motivation and commitment on the job, because motivation is central in change management. Thus, by attending to the relative presents and deprivation of support for basic psychological needs, policy makers, managers and leaders are better able to understand the sources of entrepreneurial engagement and what drives their own and others' spirit, which facilitates both personal achievement and overall economic development.

\subsection{Fiscal incentives for economic development}

Several governments have used taxation as a means of attaining policy objectives (Adair, et al., 1995). Fiscal incentives are one of the most relied upon strategies available to governments who are in need of improving economic activity and making the economic base attractive, especially in favour of the private sector (Adair, et al., 1995). The effects of taxation to an enterprise investment and entrepreneurship does not only concerns the evaluation of taxation policy and its design, but also impacts the thinking surrounding economic growth (De Long \& Summers, 1991; Barro \& Xavier, 1992; Baumol, et al., 2007).

Davis and Henreckson (2005) pointed out that taxation issues might differently affect investment in different sectors and can therefore influence the process of resource allocation between the formal and the informal sectors of the economy, hence the need for taxation policy analysis. The same notion was supported by Riding and Dunlop (2002) when they asserted that policymaking authorities are consistently working tirelessly 
to come up with ways to improve private investment (Riding \& Dunlop, 2002). Some of the suggestions they put forward as means of improving private investment include revisiting the existing taxation treatments of equity investments, capital gains, capital loses as well as a considerable review of securities regulations. Further study is however necessary to establish whether the suggested measures are warranted. Lerner (1998) however argued that a considerable degree of uncertainty still exists on the feasibility of public efforts on investment encouragement in new firms. It should therefore be appreciated that no considerable works have been carried out on ascertaining how financing programmes have to be designed to ensure they are effective (Lerner, 1998; Lerner, 2002).

Government intervention in the promotion of economic growth has remained a central element in taxation laws (Manly, et al., 2006), as such, the responses of expenditure on fixed investment to changes in taxation policy have been a subject of great debate. Chirinko (1986) argued that no sufficient empirical evidence is yet available in connection with the relationship between investment particularly capital investment and changes in taxation legislation (Chirinko, 1986). This same notion was upheld by Clark and Sichel (1993). However, Hasset and Hubbard (1996) asserted that there is positive relationship between changes in marginal investment costs and changes in taxation (Hasset \& Hubbard, 1996). According to the United Nations Global Survey (2000) a number of countries have resorted to fiscal incentives as a determinant for investment attraction, regardless of its efficacy being questionable. "In terms of the types of fiscal incentives granted, there is clearly an increasing trend towards offering full or partial tax holidays or tax rate reductions for specific types of activities" (UNCTAD 2000). It has also been noted that the other trend concerns increasing prevalence of accelerated allowances, generally for investment in property, plant and machinery. A considerable number of nations use fiscal incentives to ensure enterprise economic sustainability. The reasons behind incentivising enterprises are considerably variable, and these range from employment creation and export promotion to domestic value addition (UNCTAD 2000).

Incentive schemes for SMEs are a topical issue since it is highly characterised by information asymmetry, a phenomenon described by Berger and Udell (1988) as "informational opacity". As such, some scholars have consistently argued that for incentives to be effective, they should be directed to small and growing firms. Small and Medium Enterprises often face funding problems due to their inability to borrow from capital markets (Berger \& Udell, 1988). The funding of the small growing firms would benefit the nation through the broadening of the tax base in the long run, which is a key intermediary stage of improving governance and political development essential for improving the investment climate in developing countries. Table 1 below presents advantages and disadvantages associated with different forms of fiscal incentives.

Table 1: Pros and cons to the government of different forms of fiscal incentives

\begin{tabular}{|c|c|}
\hline ADVANTAGES & DISADVANTAGES \\
\hline & Lower Tax Rate \\
\hline $\begin{array}{l}\text { Simple to administer } \\
\text { Revenue costs are } \\
\text { more transparent }\end{array}$ & $\begin{array}{l}>\text { Largest benefits go to high-return firms that are likely to have } \\
\text { invested even without incentives } \\
\text { Invites tax avoidance through high-tax enterprises shifting profits } \\
\text { to low tax areas via transfer prising (intra-country and } \\
\text { internationally) } \\
>\text { Acts as windfalls to existing investments } \\
>\text { Unlike specific benefits, may not be tax spared by home country } \\
\text { tax authorities. }\end{array}$ \\
\hline & Tax Holidays \\
\hline $\begin{array}{l}\text { Simple to administer } \\
\text { Allows taxpayers to } \\
\text { avoid contact with tax } \\
\text { administration (which } \\
\text { may be important if it } \\
\text { is complex or corrupt) }\end{array}$ & $\begin{array}{l}>\text { Attract short-run projects } \\
\text { Invites tax avoidance through the indefinite extension of holidays } \\
\text { due via creative re-designation of existing investments as new } \\
\text { investments } \\
>\quad \text { Creates competitive distortions between old and new firms } \\
>\text { Revenue costs are not transparent unless tax filling is required, in } \\
\text { which case administrative benefits are foregone. }\end{array}$ \\
\hline & Investment allowance and Tax credits \\
\hline $\begin{array}{l}\begin{array}{l}\text { Can be targeted to } \\
\text { certain types }\end{array} \\
\text { investments } \\
\text { wighest positive } \\
\text { with } \\
\text { overs } \\
\text { Revenue costs are } \\
\text { more transparent }\end{array}$ & $\begin{array}{l}>\text { Distorts choice of capital assets in favour of short-lived ones, since } \\
\text { a further allowance is available each time an asset is replaced } \\
\text { Qualified enterprises may attempt to abuse the system by selling } \\
\text { and purchasing the same assets to claim multiple allowances } \\
>\text { Greater administrative burden } \\
\text { Discriminates against investments with delayed returns if loss } \\
\text { carry-forward provisions are inadequate. }\end{array}$ \\
\hline
\end{tabular}




\begin{tabular}{|l|l|l|}
\hline ADVANTAGES & \multicolumn{1}{c|}{ DISADVANTAGES } \\
\hline \multicolumn{2}{|l|}{$\begin{array}{l}\text { All of the benefits of } \\
\text { allowances and credits }\end{array}$} & $>\begin{array}{l}\text { Some administrative burden } \\
\text { Discriminates against investments with delayed returns if loss } \\
\text { carry-forward provisions are inadequate. }\end{array}$ \\
$>\begin{array}{l}\text { Does not generally } \\
\text { discriminate against }\end{array}$ & \\
$\begin{array}{l}\text { long-lived assets } \\
\text { Moves the distortion } \\
\text { against investment } \\
\text { typically produced by } \\
\text { the regular income tax }\end{array}$ & \\
\hline
\end{tabular}

Source: Fletcher (2002)

\subsection{The work engagement model}

The origins of the concept of work engagement can be traced to studies on the negatively framed concept of burnout (Schaufeli, et al., 2002). The burnout concept which looks exclusively on the negative role of workers' well-being, has since been rephrased as an erosion of engagement, following the emerged focus of positive psychology, focusing on human strength and optimal functioning rather than on weaknesses and malfunctioning (Seligman \& Csikszentmihalyi, 2000). As such, work engagement can best be referred to as a positive antipode of burnout (Schaufeli \& Bakker, 2004). The work engagement model emerged as a response to calls for positive constructs in occupational psychology (Cillier \& M, 2010). Work engagement can be defined as "...a positive, fulfilling, work-related state of mind that is characterised by vigour, dedication and absorption" (Schaufeli, et al., 2002). Vigour is associated with high energy levels, willingness to work and persevere regardless of circumstances, and dedication is associated with a sense of meaningfulness, a feeling of being challenged, a feeling of pride and enthusiasm and inspiration, whereas absorption concerns the idea of being fully focused on and immersed in one's work to such an extent that one becomes passive to the passing of time and finding it difficult to detach oneself from work (Schaufeli, et al., 2002; De Bruin, et al., 2013). Vigour and dedication are considered core dimensions of work engagement (Schaufeli \& Bakker, 2004), whereas absorption may be a consequence of work engagement (Langelaan, et al., 2006; De Bruin, et al., 2013).

\subsection{Economic sustainability of small to medium enterprises}

The concept of sustainability can be perfectly expressed through its three main pillars of economic, environmental and social effects (Goetz, 2010). Economic sustainability refers to the capability of an enterprise to remain in business. It concerns the propensity to generate income for a considerable time period that is in excess of operational costs. Economic sustainability concerns the idea of taking into consideration all the components of the organisation and realigning them towards the central goal, which fosters proper management of revenue and costs associated with the entity's operations (Rich, 2001). Therefore, economic sustainability can be said to be the epicentre of the business model concept (Pasmore, 1988). Considering it to be the central part of the business model concept, it therefore means viability is a critical determinant factor (Emery, 1969). Economic sustainability which is alternatively referred to as the business of staying in business (Doame \& MacGillivray, 2001), represents one of the three components of the 'triple bottom line' of enterprise sustainability. Figure 1 below illustrates the three main dimensions of sustainability and examples of means through which each can be attained.

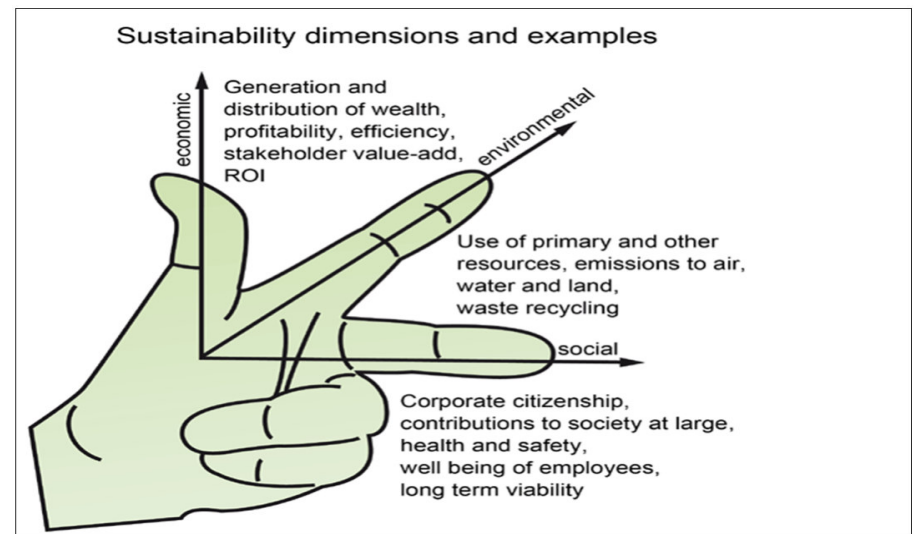

Figure 1: The three main dimensions of sustainability Source: Dyllick \& Hockerts (2002) 
For an enterprise to be referred to as being economically sustainable, it should be able to manage the three main forms of economic capital, thus, financial, tangible and intangible capital. This entails that, a holistic management approach is central to economic sustainability (Found \& Rich, 2004). Dyllick and Hockerts (2002) postulated that, "A company ceases to exist once no economic capital is left, but in reality, a company will have become unsustainable long before" (Dyllick \& Hockerts, 2002). In the context of small to medium enterprises, economic sustainability can be defined as the ability of a company to "guarantee at any time cash flow sufficient to ensure liquidity while producing a persistent above average return to its shareholders" (Dyllick \& Hockerts, 2002). Porter (1998) however argued that not all industries offer equal opportunities for sustained profitability and the inherent profitability of the industry is one essential ingredient in determining the long-term profitability of the firm (Porter, 1998). Secondly, in some industries some firms are much more profitable than others, regardless of the average profitability of the industry. Sustainability demands that a firm's competitive advantage resists erosion by competitor or industry evolution. An economically sustainable entity should ensure its main operational objectives are centred on generation and distribution of wealth, profitability, efficiency and stakeholder value-addition. It is however important to consider that in this modern dynamic environment, the traditional methods of generating profits which base dominantly on efficiency is no longer the most appropriate in achieving economic sustainability. It is therefore necessary to consider both elements of efficiency and effectiveness (Found \& Rich, 2004). In 1995, Carnell differentiated efficiency from effectiveness when he asserted that "efficiency comprises of achieving existing objectives with acceptable use of resources. Effectiveness means efficiency plus adaptability... the effective organisation is both efficient and able to modify its goals as circumstances change" (Carnell, 1995).

\subsection{Small to Medium Enterprises in Zimbabwe}

There are a number of varying definitions of Small to Medium Enterprises (SMEs) in business and economic literature. SMEs can be defined on the basis of number of employees, asset base value or revenue (Gibson \& Van der Vaart, 2008). Table 2 below illustrates how SMEs are defined by various multilateral institutions.

Table 2: SME Definitions used by Multilateral Institutions

\begin{tabular}{|c|c|c|c|}
\hline Institution & $\begin{array}{lll}\text { Maximum number } & \text { of } \\
\text { Employees } & & \\
\end{array}$ & $\begin{array}{ll}\text { Maximum } & \text { Revenue } \\
\text { Turnover }(\$) & \\
\end{array}$ & $\begin{array}{ll}\text { Maximum } & \text { Assets } \\
\text { Value }(\$) & \\
\end{array}$ \\
\hline World Bank & 300 & 15000000 & 15000000 \\
\hline IMF - IADB & 100 & 3000000 & (none) \\
\hline $\begin{array}{ll}\text { African } & \text { Development } \\
\text { Bank } & \end{array}$ & 50 & (none) & (none) \\
\hline $\begin{array}{ll}\text { Asian } & \text { Development } \\
\text { Bank } & \\
\end{array}$ & \multicolumn{3}{|c|}{ No official definition. Use only definitions of individual national governments } \\
\hline UNDP & 200 & (none) & (none) \\
\hline
\end{tabular}

Source: Gibson \& Van der Vaart, (2008).

ZIMRA has defined an SME as any business enterprise that scored nine points or less in terms of its employment levels, or turnover levels and or total net assets values (ZIMRA, 2014), these are determined in terms of section 2B of the Finance Act (Chapter 23:04) of the Republic of Zimbabwe. Points ranging from one to four are substituted in the following formula:

$\mathrm{A}+\mathrm{B}+\mathrm{C}$

Where:

A represents the average maximum total number of full-time employees during any calendar year of the enterprise;

$\mathrm{B}$ represents maximum total turnover of a business enterprise; and

$\mathrm{C}$ represents maximum gross value of assets (excluding immovable property) of the enterprise.

The factors $\mathrm{A}, \mathrm{B}$ and $\mathrm{C}$ are assigned a predetermined number of points, such that if the total sum of the formula is nine points or less the business enterprise is an SME. Table 3 below illustrate how the points are determined. 
Table 3: Points to determine whether an enterprise is an SME

\begin{tabular}{|c|c|c|c|}
\hline Base & Range & Points & Factor \\
\hline \multirow{4}{*}{ Employment Levels } & Up to 5 employees & 1 & \multirow{4}{*}{$\mathrm{A}$} \\
\hline & 6 up to 40 employees & 2 & \\
\hline & 41 up to 75 employees & 3 & \\
\hline & 76 and above & 4 & \\
\hline \multirow{4}{*}{ Annual Turnover } & Up to $\$ 50000$ & 1 & \multirow{4}{*}{$\mathrm{B}$} \\
\hline & $\$ 50001$ to $\$ 500000$ & 2 & \\
\hline & $\$ 500001$ to $\$ 1000000$ & 3 & \\
\hline & $\$ 1000001$ and above & 4 & \\
\hline \multirow{4}{*}{ Gross Value of Assets } & Up to $\$ 50000$ & 1 & \multirow{4}{*}{$\mathrm{C}$} \\
\hline & 50001 to $\$ 1000000$ & 2 & \\
\hline & $\$ 1000001$ to $\$ 2000000$ & 3 & \\
\hline & $\$ 2000001$ and above & 4 & \\
\hline
\end{tabular}

Source: ZIMRA (2014)

A scale is established by adding the points of each factor. Based on the results of the formula $A+B+C$ based on table 3 above, any score of

- 3 or 4 points means "micro enterprise"

- $\quad 5,6$ or 7 points means "small sized" enterprise

- 8 or 9 points means "medium sized" enterprise.

A score of less than three points disqualifies a business or an enterprise as an SME and therefore removes eligibility for claim to incentives such as Special Initial Allowance (ZIMRA 2014).

\section{Conceptual framework}

The conceptual framework was developed from a critical analysis of previous works by other researchers on the variables. The current study is motivated by prior studies which establish that policy decisions in form of fiscal incentives are critical pillars necessary in promoting economic sustainability of businesses. Also, literature accentuates the importance of internal people factors in defining motivation and pro-enterprising behaviour which can be used to explain and justify economic viability of small to medium enterprises even under poor and anti-enterprising economic climate. As such, the study hypothesizes that fiscal incentives and entrepreneur work engagement are positively associated with economic sustainability of SMEs in Zimbabwe. The relationship between the independent variables, fiscal incentives and work engagement and the dependent variable, economic sustainability as measured by profitability through turnover and return on investment, is illustrated in Fig 2 below;

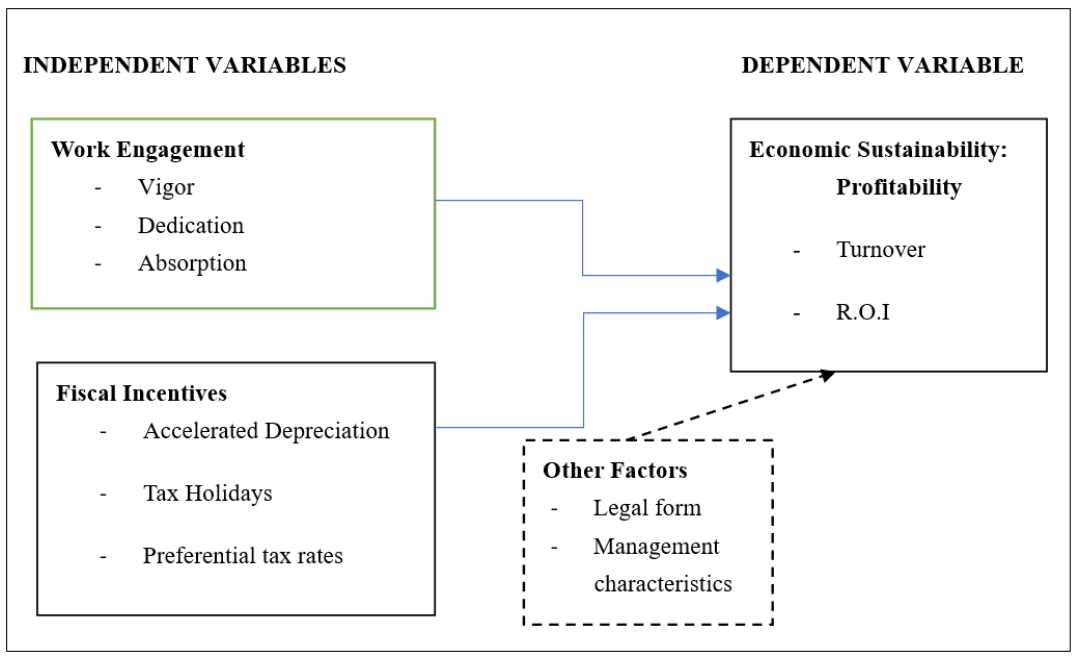

Figure 2: Conceptual framework

Source: Researcher conceptualisation, 2019.

\subsection{Measurement of variables}

4.1.1. Measuring the independent variable - Fiscal incentives

Fiscal incentives were expressed in terms of the value of benefits enjoyed by an enterprise, which in turn represents the opportunity cost to the government in terms of revenues foregone (Fisher 2010). This was assessed through establishing the availability or unavailability of fiscal incentives to an enterprise. The study 
therefore assumes that if the entrepreneur has knowledge of fiscal incentives, it therefore means incentives are available and if the entrepreneur possesses no knowledge of the incentives, it therefore means incentives are not available to their respective organisations. This perspective was taken from the notion that the taxation authority is responsible for collecting as much as it can in form of taxation for the benefit of the sovereign. As such, it is upon the individual tax payers to arrange the affairs of their businesses so as to minimise this burden. It therefore follows that, if an entrepreneur is not aware of tax incentive available or they are eligible to, the deemed benefits cannot automatically accrue to their entities, so technically the incentives are not available to their businesses and the pattern of activities for such an organisation can be explained by factors other than fiscal incentives.

4.1.2. Measuring the independent variable - Work engagement.

Work engagement for the purpose of this study was assessed using the Utrecht Work Engagement Scale (UWES) (Schaufeli, et al., 2002), which measures engagement according to the three dimensions of vigour, dedication and absorption. This scale has been validated and utilised extensively in a number of studies across national boundaries (Bakker, et al., 2008; De Bruin, et al., 2013).

4.1.3. Measuring the dependent variable - Economic sustainability

Economic sustainability was measured in terms of enterprise profitability. Profit is usually the underlying objective of every SME. It is attained when income of an enterprise surpasses operational costs. According to Richard et al (2009), it is possible to measure enterprise performance for comparative purposes using only profitability as a performance indicator. The table below summarises variables and their respective measures; Table 4: Measurement of variables

\begin{tabular}{|c|c|c|c|}
\hline & Variable & Measure & Reference \\
\hline \multirow[t]{2}{*}{$\begin{array}{l}\text { Independent } \\
\text { Variables }\end{array}$} & $\begin{array}{cl}\text { Fiscal Incentives } \\
- & \text { Tax holidays } \\
- & \text { Accelerated } \\
& \text { depreciation } \\
- & \text { Preferential } \\
& \text { rates }\end{array}$ & $\begin{array}{l}\text { Opportunity cost to the } \\
\text { government (knowledge on } \\
\text { availability of, and eligibility } \\
\text { for incentives) }\end{array}$ & $\begin{array}{l}\text { Billing, 2005; Fisher, 2010; } \\
\text { Atikah, } 2014\end{array}$ \\
\hline & $\begin{array}{cl}\text { Work Engagement } \\
- & \text { Vigour } \\
- & \text { Dedication } \\
- & \text { Absorption }\end{array}$ & $\begin{array}{l}\text { Utrecht Work Engagement } \\
\text { Scale (UWES) }\end{array}$ & $\begin{array}{l}\text { Schaufeli, et al., 2002; } \\
\text { Bakker, et al., 2008; De } \\
\text { Bruin, et al., 2013. }\end{array}$ \\
\hline $\begin{array}{l}\text { Dependent } \\
\text { variables }\end{array}$ & Economic Sustainability & $\begin{array}{l}\text { Secondary data on } \\
\text { profitability } \\
-\quad \text { Turnover } \\
-\quad \text { Return on investment }\end{array}$ & $\begin{array}{l}\text { Hicks, 1990; Richard et al., } \\
2009\end{array}$ \\
\hline
\end{tabular}

Source: Researcher, 2019

\section{Research methodology}

The study adopted a quantitative research design, gathering survey data from 120 purposively selected Zimbabwean entrepreneurs using semi-structured questionnaires. Quantitative research design was preferred because one of its underlying tenets is a philosophical belief that the world is relatively stable and uniform, such that we can measure and understand it as well as making generalisations about it. SME entrepreneurs were targeted as subjects for the purpose of the current study due to the nature of their businesses. Majority of SMEs in Zimbabwe are owner and micro-managed, hence the characteristics of the entrepreneurs, thus their knowledge and commitment plays a paramount role in determining survival and growth of their businesses, particularly given the current turbulent economic environment.

\section{Research hypothesis}

The study hypothesis was formulated from the basis of the prevailing operational environment and tax authoritytaxpayer relationship prevailing in Zimbabwe. The current situation which is characterized by low return on investments as a result of high operational costs, is a thorn in flesh for emerging businesses. This, coupled with an aggressive taxation administration system which is designed to maximize national treasury collections for the sustenance of government business at the expense of the taxpayer has proved a major stumbling block in the way of survival and growth of SMEs in Zimbabwe. In the context of business operators in Zimbabwe, the situation entails that, it is upon the owners of businesses to have knowledge on availability of and their eligibility for tax concessions, then apply the means necessary to benefit therefrom, thereby minimizing their tax burden. Otherwise the taxation authority is aimed at collecting the maximum possible revenues, to an extent of capitalizing on the ignorance and misinformation of tax payers. Hence, the onus is upon the taxpayers to arrange their affairs so as to ease the tax burden.

Literature points it as a requirement for policy makers to design the taxation policy so as not to enrich the 
treasury of a nation at an unprecedented expense of its citizens (Smith, 1976). And notwithstanding the availability of tax concessions and fiscal incentives aimed at benefiting particularly SMEs in Zimbabwe, taxation policy seems to have failed to meet the requirement. It should be appreciated that the issue is not merely centered on the crafting of policy frameworks and propagation of legislation, but rather the outcomes of these efforts. That is, the existence of policy can only materialize following its successful implementation and operationalization. Thus, after policy crafting, awareness campaigns should be held to inform potential beneficiaries, and administrative premises for such frameworks should be properly defined to ensure successful execution of the policy in line with its objectives. Specifically, Zimbabwe brag of having fiscal incentives available to and aimed at benefitting SMEs, but the administrative premises for such concessions are ill-defined and always treated in the dark. In fact, unlike other jurisdiction such as those within the Caribbean region which have specifically dedicated fiscal incentives administrative statutes, Zimbabwe does not have a specific fiscal incentives administrative framework or guideline in place to guarantee sanity when it comes to the administration of fiscal incentives and plugging-off revenue leakages inherent to the fiscal incentives regime.

The study therefore sought to empirically review the status core, inform policy and emphasize that it is and will always be government's responsibility to create a fiscal and legislative climate that is pro-enterprising (Asikhia, 2010; Dickinson, 2013). It therefore follows that, in the context of successfully operating SMEs in Zimbabwe, if the business owners lack knowledge on availability of and their eligibility for fiscal incentives, it can be interpreted that, ceteris paribus, the driving force behind their successful endeavors can be traced to entrepreneur work engagement. Work engagement refers to "a positive fulfilling, work related state of mind that is characterized by vigor, dedication and absorption" (Schaufeli \& Bakker, 2004). A work engaged entrepreneur is full of vitality, feels glued to his business and is well prepared to deal with the related business demands. It refers to a persistent, pervasive effective-cognitive state that is not focused on any particular object, event, individual or behavior (Schaufeli, et al., 2001). To assess the association between fiscal incentives and work engagement as the independent variables, and economic sustainability of SMEs in Zimbabwe using related variable measures as discussed above, the study hypothesis can be stated as:

H1: Fiscal incentives and work engagement are the key determinants of economic sustainability of SMEs in Zimbabwe.

This hypothesis has other two sub-hypotheses stated here under:

H1(a): The availability of and eligibility for fiscal incentives determines the economic sustainability of SMEs in Zimbabwe.

H1(b): Entrepreneur work engagement is the main driver of economic sustainability of SMEs in Zimbabwe.

\section{Research findings}

7.1 Reliability and validity

Cronbach's alpha as a measure of internal consistency, was used to assess scale reliability. Table 5 below indicates a Cronbach's alpha statistic of 0,744 (part 1) and 0.683 (part 2), part 1 statistic was above the 0.7 threshold indicating that items used in the study are closely related. Although part 2 statistic is slightly below the 0.7 threshold, the statistic is still deemed satisfactory for an exploratory study (Hair, et al 2010), hence, items used in the study are internally consistent.

Table 5: Reliability statistics

\begin{tabular}{llll}
\hline Cronbach's Alpha & Part 1 & Value & $\mathbf{0 . 7 4 4}$ \\
\cline { 2 - 4 } & & N of Items & $14 \mathrm{a}$ \\
\cline { 2 - 4 } & Part 2 & Value & 0.683 \\
\cline { 2 - 4 } & & N of Items & $14 \mathrm{~b}$ \\
\cline { 2 - 4 } & Total N of Items & & 28
\end{tabular}

Source: Researcher, 2019

\subsection{Categorization of respondents}

To enhance representativeness of results, study participants were drawn from across the five main sectors of the economy, being manufacturing, mining, education, agriculture and retail. Figure 3 below indicate that the retail sector has a highest number of representatives comprising $40 \%$, followed by manufacturing sector with $20 \%$, with the least being the education sector with 5\% representation. These representations are prorated, this entails that, in Zimbabwe a greater number of SMEs are in the retail industry, followed by manufacturing, agriculture, mining and lastly the education sector. 


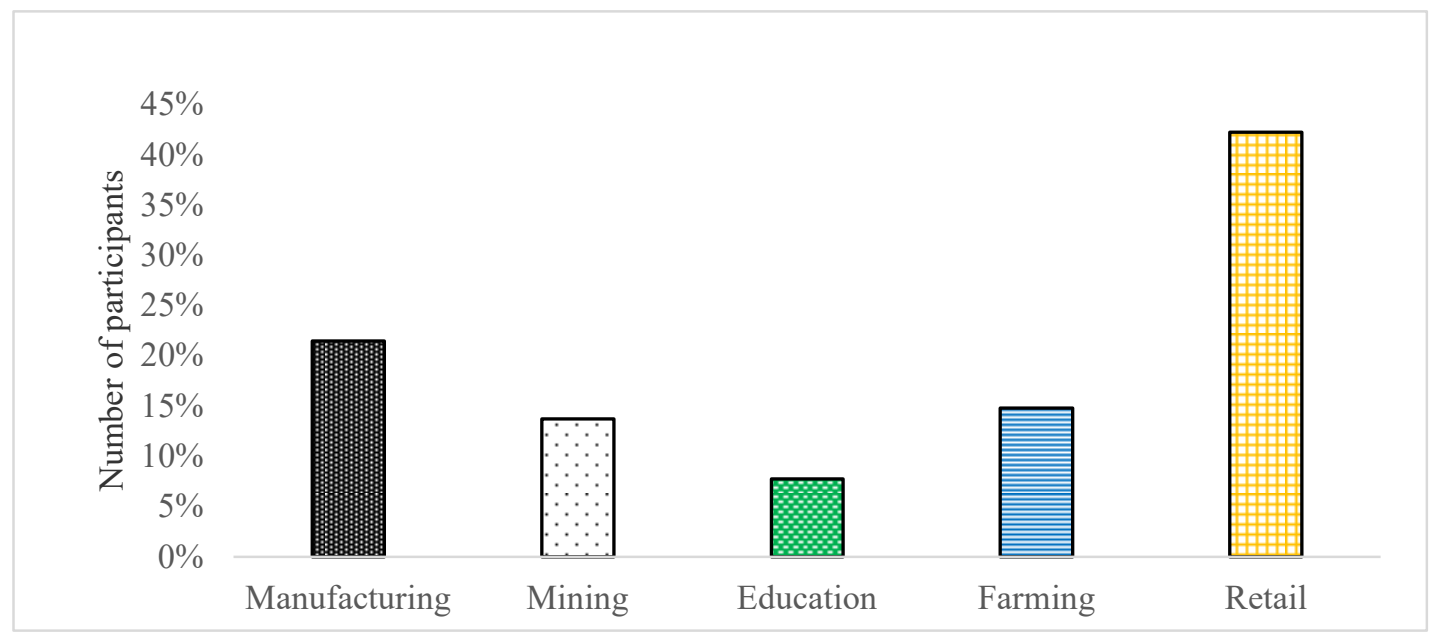

Figure 3: SME percentage representations

Source: Researcher, 2019

\subsection{Hypothesis testing}

We test the relationship between fiscal incentives \& work engagement and economic sustainability of SMEs using correlation and regression analysis. We re-state the hypotheses hereunder:

H1: Fiscal incentives and work engagement are negatively associated with economic sustainability of SMEs in Zimbabwe.

We also test the sub hypotheses re-stated here under:

H1(a): The availability of and eligibility for fiscal incentives is negatively associated with economic sustainability of SMEs in Zimbabwe.

H1(b): Entrepreneur work engagement is negatively associated with economic sustainability of SMEs in Zimbabwe.

7.3.1. Correlation analysis

Correlation analysis was performed (Table 6) to show the relationship between the independent variables (Fiscal incentives and Work engagement) and economic sustainability as the dependent variable, measured by profitability, assessed through turnover and return on investment (ROI). The results indicate that there is a significant positive correlation between fiscal incentives and ROI of 0.125 at 0.01 level of significance. The results however show that there is no significant relationship between fiscal incentives and turnover. We therefore, reject the null sub-hypothesis (H1(a): The availability of and eligibility for fiscal incentives is negatively associated with economic sustainability of SMEs in Zimbabwe). Correlation results also indicate that there is a significant positive correlation between turnover and work engagement dimension of vigour 0.013, a significant positive correlation between turnover and work engagement dimension of dedication 0.003 and also a significant positive correlation between turnover and work engagement dimension of absorption 0.007 . Correlation is significant at 0.01 level. Results further show that there is no significant relationship between work engagement dimensions of vigour, dedication and absorption and ROI. We therefore, reject the null subhypothesis (H1(b): Entrepreneur work engagement is negatively associated with economic sustainability of SMEs in Zimbabwe). 
Table 6: Correlation Fiscal incentives; work engagement and economic sustainability of SMEs

\begin{tabular}{|l|l|l|l|l|l|l|l|}
\hline Correlations & $\begin{array}{l}\text { Turnove } \\
\mathrm{r}\end{array}$ & ROI & Vigor & $\begin{array}{l}\text { Dedicatio } \\
\mathrm{n}\end{array}$ & $\begin{array}{l}\text { Absorptio } \\
\mathrm{n}\end{array}$ & $\begin{array}{l}\text { Fiscal } \\
\text { Incentive }\end{array}$ \\
\hline Turnover & $\begin{array}{l}\text { Pearson } \\
\text { Correlation }\end{array}$ & 1.000 & & & & & \\
\hline ROI & $\begin{array}{l}\text { Pearson } \\
\text { Correlation }\end{array}$ & $.347^{* *}$ & 1.000 & & & & \\
\hline Vigor & $\begin{array}{l}\text { Pearson } \\
\text { Correlation }\end{array}$ & $0.013^{* *}$ & -0.020 & 1.000 & & & \\
\hline Dedication & $\begin{array}{l}\text { Pearson } \\
\text { Correlation }\end{array}$ & $0.003^{* *}$ & 0.096 & $\begin{array}{l}.318^{*} \\
*\end{array}$ & 1.000 & & \\
\hline Absorption & $\begin{array}{l}\text { Pearson } \\
\text { Correlation }\end{array}$ & $0.007^{* *}$ & 0.036 & $\begin{array}{l}.551^{*} \\
*\end{array}$ & $.461^{* *}$ & 1.000 & \\
\hline $\begin{array}{l}\text { Fiscal } \\
\text { Incentive }\end{array}$ & $\begin{array}{l}\text { Pearson } \\
\text { Correlation }\end{array}$ & -0.005 & $\begin{array}{l}0.125^{*} \\
*\end{array}$ & 0.060 & 0.070 & 0.034 & 1.000 \\
\hline
\end{tabular}

Source: Researcher, 2019

We can therefore conclude that there is a positive relationship between fiscal incentives and economic sustainability of SMEs as measured by profitability expressed through ROI. We also conclude that there is a positive relationship between work engagement and economic sustainability of SMEs as measured by profitability expressed through turnover.

7.3.2. Regression analysis

Regression analysis table 7 (a) indicates that there is a negative relationship between fiscal incentives and turnover, results being significant at 0.05 level of significance. Table 7 (b) indicates the existence of a significant positive relationship between fiscal incentives and ROI at 0.05 level. This leads to the conclusion of rejecting the null sub hypothesis H1 (a) that the availability of and eligibility for fiscal incentives is negatively associated with economic sustainability of SMEs in Zimbabwe.

Table 7 (a): Regression: Fiscal incentives; work engagement and turnover

\begin{tabular}{llllll}
\hline & Estimate & Std. Error & $\mathrm{t}$ value & $\operatorname{Pr}(>|\mathrm{t}|)$ & Sig. \\
\hline (Intercept) & 0.499467 & 0.245615 & 2.034 & 0.0429 & $*$ \\
\hline Work Engagement & 0.2163 & 0.002888 & 1.038 & 0.006 & $* * *$ \\
\hline Fiscal Incentive & -0.31011 & 0.042953 & -0.235 & 0.001 & $* * *$ \\
\hline
\end{tabular}

Dependent variable: Turnover

Source: Researcher, 2019

Regression results table 7 (a) reveal the existence of a significant positive relationship between work engagement as expressed through its dimensions of vigour, dedication and absorption and turnover at 0.05 level of significance. Table 7 (b) also indicates the existence of a significant positive relationship between work engagement and ROI. This leads to the conclusion of rejecting the null sub-hypothesis H1(b) that entrepreneur work engagement is negatively associated with economic sustainability of SMEs in Zimbabwe.

Table 7(b): Regression: Fiscal incentives; work engagement and ROI

\begin{tabular}{llllll}
\hline & Estimate & Std. Error & t value & $\operatorname{Pr}(>|\mathrm{t}|)$ & Sig. \\
\hline (Intercept) & 0.268231 & 0.224 & 1.195 & 0.000 & $* * *$ \\
\hline Work Engagement & 0.2404 & 0.264 & 0.911 & 0.003 & $* * *$ \\
\hline Fiscal Incentive & 0.2237 & 0.392 & 0.057 & 0.005 & $* * *$ \\
\hline
\end{tabular}

Dependent variable: ROI

Source: Researcher, 2019

From the regression analysis results, it can be concluded that the existence of and eligibility for fiscal incentives is positively associated with economic sustainability of SMEs in Zimbabwe as expressed by profitability assessed through ROI. It can also be concluded that entrepreneur work engagement is positively associated with economic sustainability of SMEs in Zimbabwe.

\section{Discussion}

The persistently prevailing negative economic conditions in Zimbabwe have rudely awakened the nation to realisation of the importance of the role played by SMEs in enhancing livelihoods, poverty alleviation and fostering economic growth. Hence, the need to map SMEs within the economic development highway, by increasing attention towards the sub-sector. Yet the growing acrimony between SMEs and the taxation authority (ZIMRA) over the years seem to parade lack of policy alignment, consistency and goal congruency. Of late, Zimbabwe has seen an increase in the number of both artisanal and registered SMEs. This follows the continued 
economic meltdown whose results can be clearly seen through the ballooning rate of unemployment and the increasing number of companies turning in to white elephants, which were formerly productive companies if not 'industries' in themselves, that the nation used to be reckoned with. This realisation of the importance of SMEs has fostered the need to explore the main drivers behind the economic sustainability of SMEs in Zimbabwe. Assessing specifically the impact of external public policy factors in terms of fiscal incentives and internal people factors intrinsic to individual businesses in terms of entrepreneur work engagement. This study aimed at informing policy direction through the establishment of a more satisfactory descriptive theory for a broader approach to economic sustainability of SMEs in Zimbabwe.

The study findings reveal that there is a statistically significant positive relationship between fiscal incentives and economic sustainability of SMEs in Zimbabwe, assessed through profitability as measured by ROI. The study making use of performance measures of profitability also established the existence of a positive relationship between entrepreneur work engagement and economic sustainability of SMEs in Zimbabwe, assessed through profitability as measured by turnover. The study however established that most entrepreneurs in Zimbabwe lack knowledge on availability of and their eligibility for fiscal incentives. It therefore follows that; most thriving SMEs in Zimbabwe are sustained by internal people factors more than the effects of external policy factors. This finding is in line with literature which demeans the role of fiscal incentives, viewing them as a wastage of state resources which could have been used to provide public services, given that majority of the beneficiaries of the incentives are likely to be economic players who would have contributed nothing in line with the government's objectives (Fisher, 2010) and who in actual fact would have done nothing differently and nothing they could not have done without being incentivised. Results also confirm conclusions by some scholars who advocated against fiscal incentives, pointing to the rampant nature of information opacity (Berger \& Udell, 1988) associated with the regime and its preferential treatment nature (Fletcher, 2002), which results in equity violations which are usually overlooked (King \& Don, 1984), mainly the violation of horizontal equity (equal treatment of equals).

The study also established that a considerable number of entrepreneurs in Zimbabwe were forced into establishing businesses due to poor economic conditions, a typical case being of university graduates' failure to secure employment after completing their studies. This revelation therefore, confronts the SD theory which points that entrepreneurs are in business because of their business enthusiasm driven by their natural sense of competence, autonomy and relatedness which tent to emotionally bond them and their business endeavours. In the light of such establishments, the SD theory proved a limited insight into the psychological mechanisms involved in driving entrepreneurial spirit.

\section{Conclusion}

The study investigated the impact of fiscal incentives and work engagement on economic sustainability of SMEs in Zimbabwe. The study established that there is a significant positive relationship between fiscal incentives and work engagement and economic sustainability of SMEs in Zimbabwe. Internal people factors proved to have the greatest contribution in defining the current state of thriving SMEs, when compared to the effects of fiscal incentives thereto. The study concludes that if properly administered, fiscal incentives have the potential to contribute more towards survival and growth of SMEs in Zimbabwe, a move that will benefit the nation through broadening of the tax base in the long run, which is a key intermediary stage of improving governance and political development essential for improving the investment climate in a developing country. The study therefore recommends the establishment of clearly defined fiscal incentives administration grounds, a move that can be easily facilitated by the promulgation of a specific fiscal incentive administrative statute, the Fiscal Incentives Act.

\section{References}

Adair, A., Berry, J. \& McGreal, S., 1995. Fiscal policy, taxation incentives and inner-city housing development. Housing Studies, 10(1).

Alan, P. \& Fisher, P., 2004. The failures of economic development incentives. Journal of the American development Incentives, 70(1).

Aleksandra , B., Claudia , B., Thomas , R. \& Petra, L., 2017. Task-level work engagement of self-employed and organizationally employed high-skilled workers. Career Development International, 22(6), pp. 724-738.

Asikhia, O. U., 2010. SMEs and pooverty alleviation in Nigeria: Marketing resources and capabilities implications. New England Journal of Entrepreneurship, 13(2), pp. 57-70.

Bakker, A. B., Schaufeli, W. B., Leiter, M. P. \& Taris, T. W., 2008. Work engagement: An emerging concept in occupational healthy psychology. Work and Stress, 22(3).

Baregheh, A., Rowley, J., Sambrook, S. \& Davies, D., 2012. Food sector SMEs and innovation types. British Food Journal, 114(11), pp. 1640-1653.

Barro, R. J. \& Xavier, S., 1992. Public Finance in models of economic growth. The Review of Economic Studies , 
59(4), pp. 645-661.

Baumeister, R. \& Leary, M., 1995. The need to belong: Desire for interpersonal attachments as a fundamental human motivation. Psychological Bulletin, Volume 117, pp. 497-529.

Baumol, W. J., Litan, R. \& Schramm, C. J., 2007. Good capitalism, bad capitalism. New Haven: Yale University Press.

Berger, A. N. \& Udell, G. F., 1988. The Economics of small business finance: The role of private equity and debt markets in the financial growth cycle. Journal of Banking and Finance, 22(6-8), pp. 613-673.

Boadway, R. \& Shar, A., 2007. Fiscal federalism. Principles and practice of multiorder governance. Governance and Accountability series.

Carnell, C., 1995. Managing change in organisations. Hemel. Hempstead: Prentice Hall.

Chirinko, R. S., 1986. Will the Neo-Classical theory of investment please rise? The general structure of investment models and implications for tax policy. Mimeo: s.n.

Cillier, F. \& M, M., 2010. The popularisation of positive psychology as a defense against behavioural complexity in research and organisations. SA Journal of Industrial Psychology, 36(2), pp. 1-10.

Connell, J. P. \& Wellborn, J. G., 1991. Comptence, autonomy and relatedness: A motivational analysis of selfsyatem processes. In: Minnesota Symposium on Child Psychology, Vol 22. s.1.:s.n., pp. 43-77.

De Bruin, G. P., Hill, C. M. \& Muller, K. P., 2013. Dimentionality of the UWES - 17: An item response modeling analysis. SA Journal of Industrial Psychology, 39(2).

De Charms, R., 1968. Personal Causation. New York: Academic Press.

De Long, J. B. \& Summers, L. H., 1991. Equipment investment and economic growth. The Quarterly Journal of Economics, 106(2), pp. 445-502.

Deci, E. L., 1975. Intrinsic motivation. New York: Plenum.

Deci, E. L. \& Ryan, R. M., 1991. A motivational approarch to self: Integration in personality.. Perspectives on motivation, Volume 38, pp. 237-288.

Deci, E. L. \& Ryan, R. M., 1995. Human autonomy: The basis for true esteem. In: M. Kernis, ed. Efficacy, agency and self esteem. New York: Plenum, pp. 31-49.

Dickinson, P. G., 2013. SMEs and the business reality of Estonia's tax regulation environment. International Journal of Law and Management, 55(4), pp. 273-294.

Doame, D. \& MacGillivray, A., 2001. Economic sustainability: The business of staying in business. s.1.:s.n.

Dyllick, T. \& Hockerts, K., 2002. Beyond the business case for corporate sustainability. Business Strategy and the Environment, 11(2), pp. 130-141.

Emery, F., 1969. Systems thinking. London: Penguin.

Fisher, P., 2010. Corporate taxes and Califonia's economic growth. s.1.:Economic Policy Institute.

Found, P. \& Rich, N., 2004. Making it all add up: A systems approarch to economic systems. s.1.:Cardiff Logistics Operations Management Working paper.

Gaynor, G., 2002. Innovation by Design: What it Takes to Keep Your Company on The Cutting Edge. New York(NY): AMACOM American management association.

Gibson, T. \& Van der Vaart, H. J., 2008. Defining SMEs: A less imperfect way of defining small and medium enterprises in developing countries. s.1.:Bookings Global Economy and Development.

Goetz, K. S., 2010. Encouraging sustainable business practices using incentives: A practitioners' view. Management Research Review, 33(11), pp. 1042-1053.

Harter, S., 1978. Effectance motivation reconsidered: Towards a developmental model. Human Development, Volume 1, pp. 661-669.

Hasset, K. A. \& Hubbard, R. G., 1996. Tax policy and investment. s.1.:National Bureau of Economic Research.

Heider, F., 1958. The psychology of interpersonal relations. New York: Wiley.

Ishengoma, E. K. \& Kappel, R., 2006. Economic growth and poverty: Does formalisation of informal enterprises matter?. Hamburg: GIGA Working Papers.

Johnson, F. A., 1993. Dependency and Japanese socialisation. New York: Wiley.

King, M. \& Don, F., 1984. The taxation of income from capital: A comperative study of the US, UK, Sweden and West German. Chicago: University of Chicago Press.

Kirkby, D. \& Watson, A., 2003. Small firms and economic development in developed and transition economies. Aldershot: Ashgate.

Koves, A., 1992. Central and East European economies in transition, the international dimension. Budapest: Akademic Kiado.

Langelaan, S., Bakker, A. B., Van Doornen, L. J. P. \& Schaufeli, W. B., 2006. Burnout and work engagement: Do individual differences make any difference?. Personality and Individual Differences, Volume 40, pp. 521-532.

Lerner, J., 1998. "Angel" financing and public policy : An overview. Journal of Banking and Finace, pp. 773783. 
Lerner, J., 2002. When bureaucrats meet entrepreneurs: The design of effective " public venture capital" programmes. Economic Journal, Volume 112, pp. F73-F84.

Lipsey, R., 2007. Economics. New York: Oxford University Press.

Manly, T. S., Deborah, W. \& Schulman, C. T., 2006. Taxation incentives for economic growth growth: Capital investment or research. A Journal of Advances in Taxation, Volume 17, pp. 95-120.

Muntaha, B., Patricia, L. \& Jawad, S., 2013. Is work engagement gendered?. Gender in Management: An International Journal, 28(7), pp. 400-423.

Muvuma, T., Mujajati, C. \& Mufute, B., 2005. Economic reforms: The case of Zimbabwe. Oxford: Maldern MA, Blackwell Press.

Nix, G., Ryan, R. M., Manly, J. B. \& Deci, E. L., 1999. Revitalisation through self-regulation: The effect of autonomouse and controlled motivation on hapiness and vitality. Journal of Experimental Social Psychology, Volume 35, pp. 266-284.

Nyoni, S., 2002. Micro and medium enterprises: Policy and strategy. s.1.:s.n.

Osim, E. E., 2010. Promoting SMEs in Nigeria: A panacia for realisation of financial system strategy (FSS 2020). s.l.:s.n.

Pasmore, W., 1988. Designing effective organisations. The STS perspective. New York: Wiley.

Peters, T. \& Waterman, R., 1982. In Search of Excellence. New York: Harper \& Row.

Porter, M., 1998. Competitive advantage. Creating and sustaining superior performance. 2nd ed. New York: Free Press.

Poutziouris, P., Binks, M. \& Bruce, A., 1999. A problem-based phenomenological growth model for small manufacturing firms. Journal for Small Business and Enterprise Development, 6(2), pp. 139-152.

Reis, H. T., 1994. Dormains of experience: Investigating relationship processes from three perspectives. In: Theoretical Frameworks for Personal relationships. s.l.:s.n., pp. 87-110.

Richa , C., Santosh , R. \& Mukesh , K., 2012. "Relationships between occupational self efficacy, human resource development climate, and work engagement", Team Performance Management. An International Journal, 18(7), pp. 370-383.

Rich, N., 2001. Turning Japanese?. s.1.:PhD Thesis, Cardiff Business School, University of Wales. Cardiff.

Riding, A. \& Dunlop, R., 2002. Research issues: Financing new technology firms. Industry Canada: National Reseacrh Program in Financial Services and Public Policy.

Robert , E. \& Ankli , R., 2012. "Enabling a motivated workforce: exploring the sources of motivation", Development and Learning in Organizations. An International Journal, 26(2), pp. 7-10.

Ryan, R. M., Deci, E. L. \& Grolnick, W. S., 1995. Autonomy, relatedness and the self: Their relation to development and psychopathology. In: D. Cicchetti \& D. J. Cohen, eds. Developmental psychology: Theory and methods. New York: Wiley, pp. 618-655.

Ryan, R. M., Kulh, J. \& Deci, E. L., 1997. Nature and autonomy: Organisational views of social and neurobiological aspects of self regulation in behaviour and development. Development \& Psychopathology, Volume 9, pp. 701-728.

Salavou, H. \& Lioukas, S., 2003. Radical product innovations in SMEs: the dominance of entrepreneurial orientation. Creativity and Innovation Management, 12(2), pp. 94-108.

Schaufeli, W. B. \& Bakker, A. B., 2001. Work and well-being: Towards a positive occupational health psychology. Gedrag \& Organisatie, pp. 229-253.

Schaufeli, w. B. \& Bakker, A. B., 2004. Job demands, job resources, and their relationship with burnout and engagement: A multi-sample study. Journal of Organisational Business, Volume 25, pp. 293-315.

Schaufeli, W. B., Leiter, M. P., Maslach, C. \& Jackson, S. E., 1996. Maslach Burnout Inventory - General Survey. In: C. Maslach, S. E. Jackson \& M. P. Leiter, eds. The Maslach Burnout Inventory - Test Manual, 3rd Edn. Califonia: Consulting Psychologists Press.

Schaufeli, W. B., Salanova, M., Gonzale-Roma, V. \& Bakker, A. B., 2002. The measurement of engagement and burnout: A two sample confirmatory factor analytic approarch. Journal of Hapiness Studies, Volume 3, pp. 71-92.

Schaufeli, W. B. et al., 2001. Does work make healthy? In search of the engaged worker. De Psychololoog, Volume 36, pp. 422-428.

Seligman, M. E. P. \& Csikszentmihalyi, M., 2000. Positive Psychology: An introduction. American Psychologist, Volume 55, pp. 5-14.

Shar, A., 2006. Fiscal incentives for investment and innovation. s.1.:World Bank.

Sheldon, K. M., Ryan, R. M., Rawsthorne, L. \& IIardi, B., 1997. Trait self and true self: Cross-role varioation in the big five traits and its relations with authenticity and subjectiv well-being. Journal of Personality and Social Psychology, Volume 73, pp. 1380-1393.

Smith, A., 1976. An Inquiry into the nature and causes of the weath of nations. Glasgow: Oxford Press.

Stoneman, C. \& Thompson, C., 1994. Banking on the hunger: Food security in Zimbabwe. s.1.:Southern African 
Reort.

Udechukwu, F. N., 2003. Survey of small and medium scale industries and their potential in Nigeria. Nigeria: s.n.

Upasna, A., 2013. Linking justice, trust and innovative work behaviour to work engagement. NITIE, 43(1), pp. 41-73.

Van den Broeck, A. et al., 2011. Understanding workaholics' motivations: A self-determination perspec- tive. Applied Psychology: An International Review, 60(4), pp. 600-621.

White, R. W., 1963. Ego and reality in psychoanalytic theory. New York: International University Press.

Zee, H. H., Stotsky, J. G. \& Ley, E., 2002. Tax incentives for business investment: A primer for policy makers in developing countries. World Development, 30(9), pp. 1497-1516.

First Author - Moses Jachi

Moses Jachi is a Lecturer in the Department of Accounting at Manicaland State University of Applied Sciences. $\mathrm{He}$ is the corresponding author

\section{Second Author - Nevermind Muchongwe}

Nevermind Muchongwe is a Lecturer in the Department of Human Resource Management at Manicaland State University of Applied Sciences. He shares vested research interests in Performance Management, Industrial Democracy, Knowledge Management and Employee Engagement. 